\title{
Takäful demand: a review of selected literature
}

\author{
Maizaitulaidawati Md Husin \\ Azman Hashim International Business School, \\ Universiti Teknologi Malaysia, Kuala Lumpur, Malaysia, and \\ Razali Haron \\ IIUM Institute of Islamic Banking and Finance, Kuala Lumpur, Malaysia
}

Received 25 March 2019 Revised 1 May 2019 3 August 2019 2 September 2020 9 September 2020 Accepted 9 September 2020

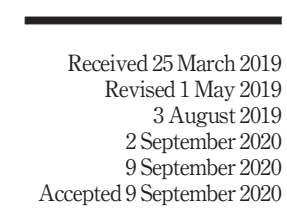

\begin{abstract}
Purpose - This paper aims to provide a systematic review of literature on the demand for takâful (Islamic insurance) from articles published from January 2009 to June 2019. The review aims to synthesise and segment previously published research to identify the gaps and provide future research direction.

Design/methodology/approach - A systematic review of the literature was conducted. Past research was analysed, and content comparisons based on research focus, context and methodology were evaluated.

Findings - It was found that not much has been written and published on takâful demand in quality journals. The first two articles were published in 2009, but it was only in 2017 that coverage of the topic rapidly expanded. Although no article was found to have been published in 2018 on takâful demand, there was one published article on the topic in 2019. This paper also found that not much attention has been given to takâful demand from the corporate sector.

Research limitations/implications - The defined rule for document searching and selection excluded out-of-scope documents that might be relevant. Furthermore, as this paper concentrates exclusively on articles published in English journals, the possibility that other relevant works do appear elsewhere in a different language is not denied.

Practical implications - Factors determining takâful demand are provided, and general directions are discussed, which managers can use to develop market share further.

Originality/value - Such an extensive review of literature on takâful demand has not been done before. Other than revealing ambiguities, gaps and contradictions in the literature, this paper sketches an avenue for further research. It also provides information and guidance for other researchers wishing to embark on research on takäful demand.
\end{abstract}

Keywords Demand, Islamic insurance, Takāful

Paper type Literature review

\section{Introduction}

Research on takaful (Islamic insurance) has received much attention in recent years in tandem with the significant progress and development of the takâful industry. According to Research and Markets (2018), the world's takâful market is projected to exceed US\$40bn by 2023 at a compounded annual growth rate of $13 \%$ over the period 2017-2023. Various

(C) Maizaitulaidawati Md Husin and Razali Haron. Published in ISRA International Journal of Islamic Finance. Published by Emerald Publishing Limited. This article is published under the Creative Commons Attribution (CC BY 4.0) licence. Anyone may reproduce, distribute, translate and create derivative works of this article (for both commercial and non-commercial purposes), subject to full attribution to the original publication and authors. The full terms of this licence maybe seen at http:// creativecommons.org/licences/by/4.0/legalcode 
factors are contributing to the growth of takâful markets, including a sophisticated business environment (EY, 2013), robust regulatory and supervisory framework (Berkem, 2014; EY, 2015) and an increasing population (Al-Amri, 2015). Saudi Arabia is dominating the takâful market in the Gulf Cooperation Council, while Malaysia is dominating the takâful market in Southeast Asia. In some countries such as Australia, the UK and Malaysia, takā ful operators and conventional insurance companies are in intense competition to gain market share. In Malaysia, for example, as of June 2020, there are 15 takâful operators and 22 conventional insurance companies operating in the market (BNM, 2020).

The takâful industry worldwide has documented a total direct premium of $2 \%$, while its conventional counterpart has only recorded $1.5 \%$. In addition, for the six-year period 20122017, the takâful industry's contributions grew at a compound average growth rate of almost 6.9\% (Islamic Financial Services Board, 2019). While takāful has recorded strong growth as compared to its conventional counterpart, takâful demand has only recently received research attention, especially regarding issues of low penetration (Ibrahim et al., 2015; EFG, 2016; Milliman, 2017) and huge market potential (Islamic Financial Services Board, 2017).

According to Best (2013), the development and demand for takaful are on the rise since 2012 because of increased awareness of the products. This leads to the following questions:

Q1. Is research on takâful demand increasing in tandem with the popularity of takâful products worldwide?

Q2. What are the relevant factors affecting demand?

Q3. In which countries has relevant research been concentrated?

This paper revisits research conducted in the area of takâful and provides a systematic literature review on factors affecting takäful demand from articles published from January 2009 to June 2019. The review aims to synthesise previously published research to explore and identify what actually drives takâful demand. Gaps and directions for future research will be identified and discussed.

The paper is structured as follows. It starts by providing an overview of the takaful industry, which is followed by a deliberation of the methodology and approach adopted in this review paper. Next, the content analysis and segmentation of past literature on takâful demand are presented and discussed. Finally, the limitations of the research methodology, gaps in previous research and future research areas are discussed in the conclusion section.

\section{A brief overview of takäful}

Takâful, a Sharī'ah-compliant alternative to conventional insurance, began in 1979 (Aziz et al., 2019). Takāful is divided into two types, namely, general and family takāful. General taka ful, known as general insurance in the mainstream market, provides financial protection to participants (known as "policyholders" or the "insured" in conventional insurance) from general losses such as burglary, flood and fire. Family takâful, known as life insurance in the conventional insurance industry, provides financial protection to participants against perils associated with death, critical illness and disability.

Several characteristics differentiate takâful from conventional insurance.

- Firstly, an insurance contract is based on a sale and purchase relationship whereby the insured pays a certain amount of money (also known as a premium payment) to the insurer in exchange for financial protection against potential risk. As the insurer and insured do not know whether the trigger event will or will not occur, an 
insurance contract is characterised by a high level of uncertainty. This situation leads to the existence of an excessive degree of gharar (uncertainty), which must be avoided in an exchange contract according to the Sharī'ah (Islamic law). Takâful, on the other hand, is based on a tabarru' (mutual cooperation) contract, which is not subject to the same rules (EY, 2013).

- Secondly, the process of compensation distribution in conventional insurance is not according to Sharīah principles. For example, if the insured dies earlier than the maturity period stated in the insurance policy, beneficiaries will receive the compensation accordingly. However, in the operation of takaful, only heirs of the participants will receive compensation according to the law of fara' $i d$ (inheritance).

- Thirdly, in the operation of takâful, profit made from Sharī'ah-approved investment activities will be distributed to participants and shareholders in accordance with the profit-sharing ratio or any other model approved prior to takâful participation. On the other hand, in the operation of conventional insurance, profits belong solely to the insurance company's shareholders.

- Fourthly, elements of maysir (gambling) exist in the operation of conventional insurance because the premium paid by policy holders and the indemnity provided by the insurer upon a claim are both uncertain. In taka ful, on the other hand, the principle of tabarru' (donation) exists whereby takâful participants mutually agree to help each other against a defined loss. Under the principle of tabarru, the uncertainty in the payout to policy holders does not lead to the issue of maysir given tabarru' does not fall within the category of exchange contracts where the element of maysir is not tolerated.

- Fifthly, compared to takâful operators who can only invest the money in selected investments, which are approved by the Sharīah, conventional insurance has no investment limitation, which generates the element of riba (interest) (Husin and Rahman, 2016).

\section{Method}

Following Tranfield et al. (2003), a three-step process of a systematic literature review is conducted as shown in Figure 1.

The review process starts with an identification of keywords. The first keyword is "demand" while the second set of keywords comprises "Islamic insurance" and takâful. For the articles to be selected, the articles' title, keywords or abstract must include a combination of the two chosen keywords. All relevant and identified articles published in English within the period January 2009 to June 2019 were included only if these two inclusion criteria were fulfilled.

Firstly, in the selection process, only articles in the Impact Factor and Scopus indexed journals were selected, to ensure the high quality of the articles. An initial search in the Web of Science using "Islamic insurance" and "demand" as keywords resulted in 12 articles, while keywords taka ful and "demand" resulted in 9 articles. On the other hand, an initial search in Scopus-indexed journals using keywords "Islamic insurance" and "demand" resulted in 22 articles, while keywords takâful and "demand" resulted in 22 articles. The search results were further examined to check for redundancy, thus leaving 13 articles for further analysis.

Secondly, following Tranfield et al. (2003), articles were skimmed further to ensure their relevancy. Subsequently, 48 articles were omitted from further analysis due to the fact that 


\section{IJIF \\ 12,3}

Figure 1.

The process of systematic literature review

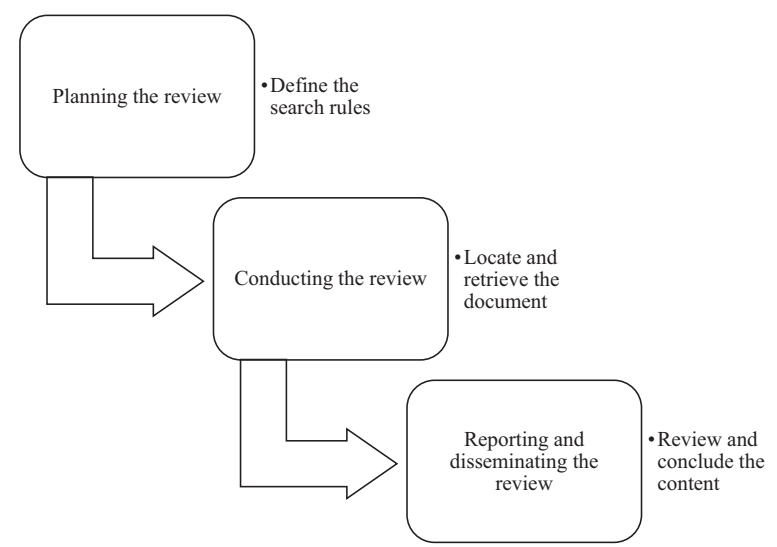

Source: Tranfield et al. (2003)

the articles primarily focussed on Islamic banks and made no reference to takâful. Moreover, some articles were found to be concerned with conventional insurance research only, and two articles turned out to be proceedings papers. As such, only the remaining 13 articles were used for analysis. In this paper, the content of the articles was compared based on the following:

- Research focus: this refers to the publications' brief coverage in terms of content and applicability.

- Research context: this looks at the environment in which the literature was conducted.

- Methodology evaluation: this observes the analysis section of the articles.

Other than distinguishing content, this paper also presents the characteristics of the articles under investigation, which include publication name, author(s) name, year of publication and journal of publication and indexing, as shown in Table 1 . In addition, Table 2 shows the inclusion and exclusion criteria used in this paper.

\section{Content analysis}

In this section, the segmentation framework (Figure 2) is presented and a summary of the literature content is briefly discussed. Four main segments - notably research area, research data, research method and factors affecting demand - were generated in an attempt to identify the essence of the takâful-demand research.

\section{Research area}

This paper classifies the research areas into two according to the type of takāful, namely, general and family. From the 12 articles, three focussed on takâful demand in general, four concentrated on family takâful demand, while the remaining five focussed on both. For instance, Sherif and Shaairi (2013) discussed the factors influencing family takâful demand by identifying economic and socio-demographic variables in the Malaysian context. Other articles that also focussed on family takäful demand are Zerriaa and Noubbigh (2016), Hassan et al. (2017) and Sherif and Ahmed (2017). 


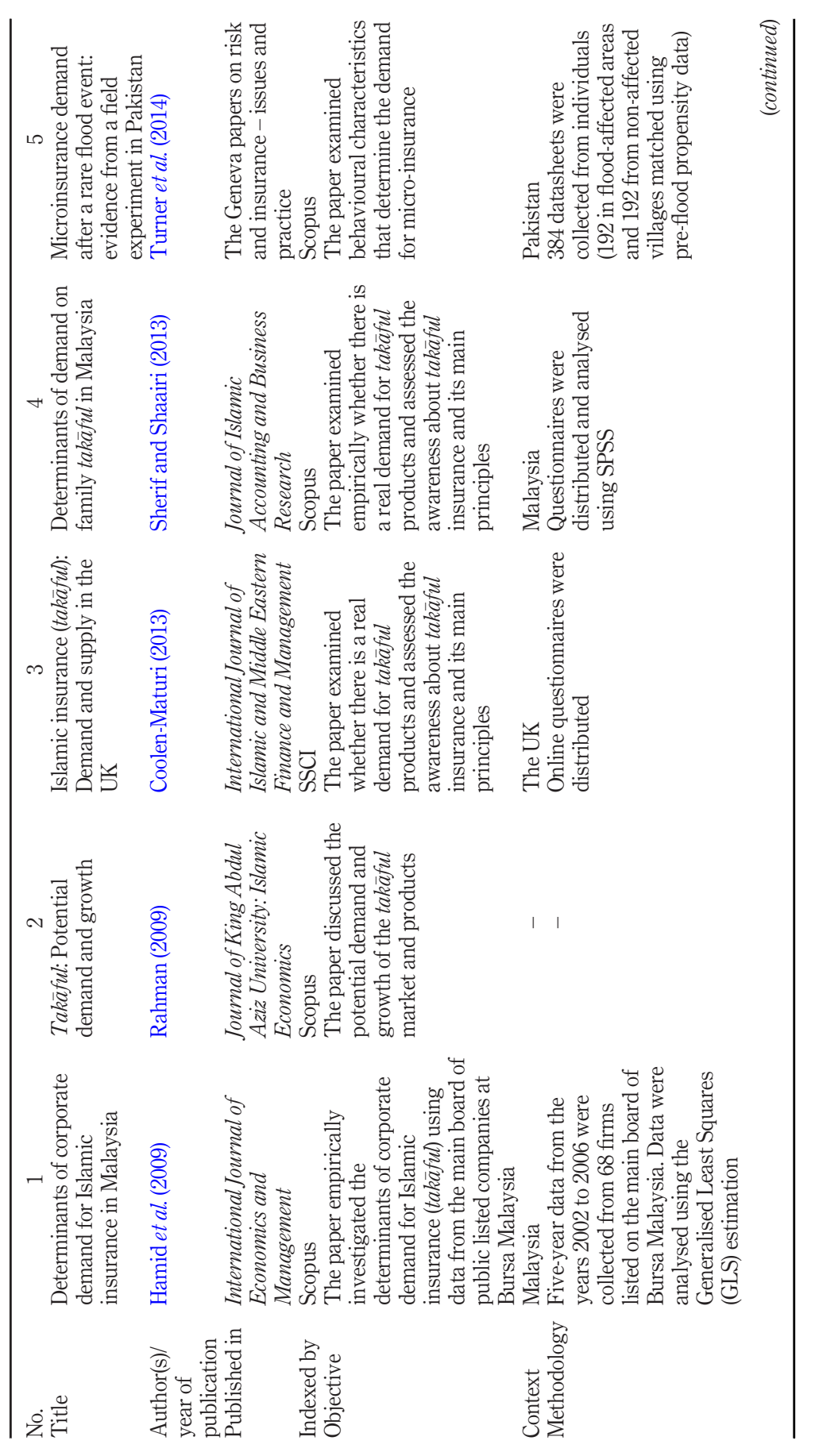

Takāful demand

Table 1. An overview of previous literature on takāful demand 


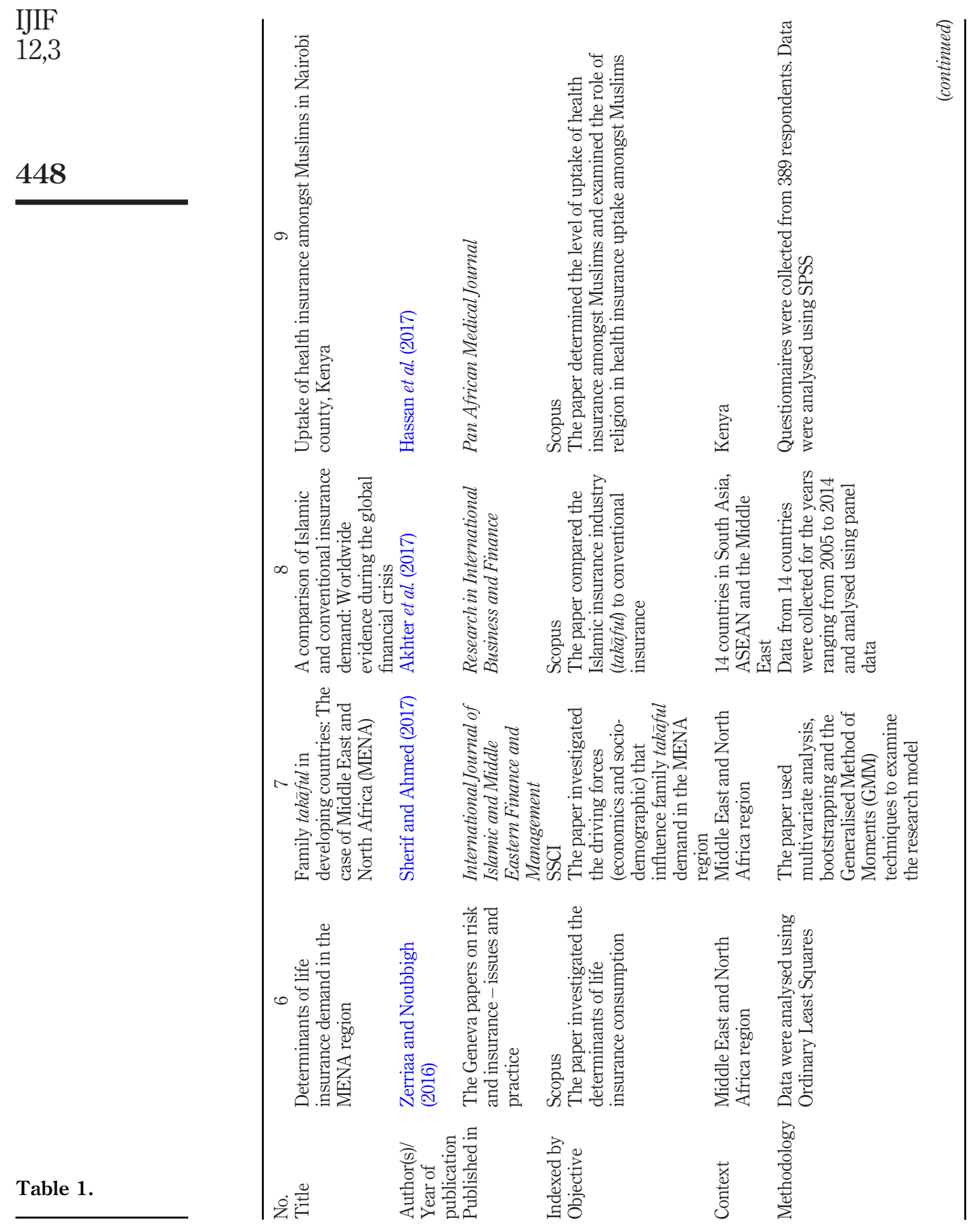




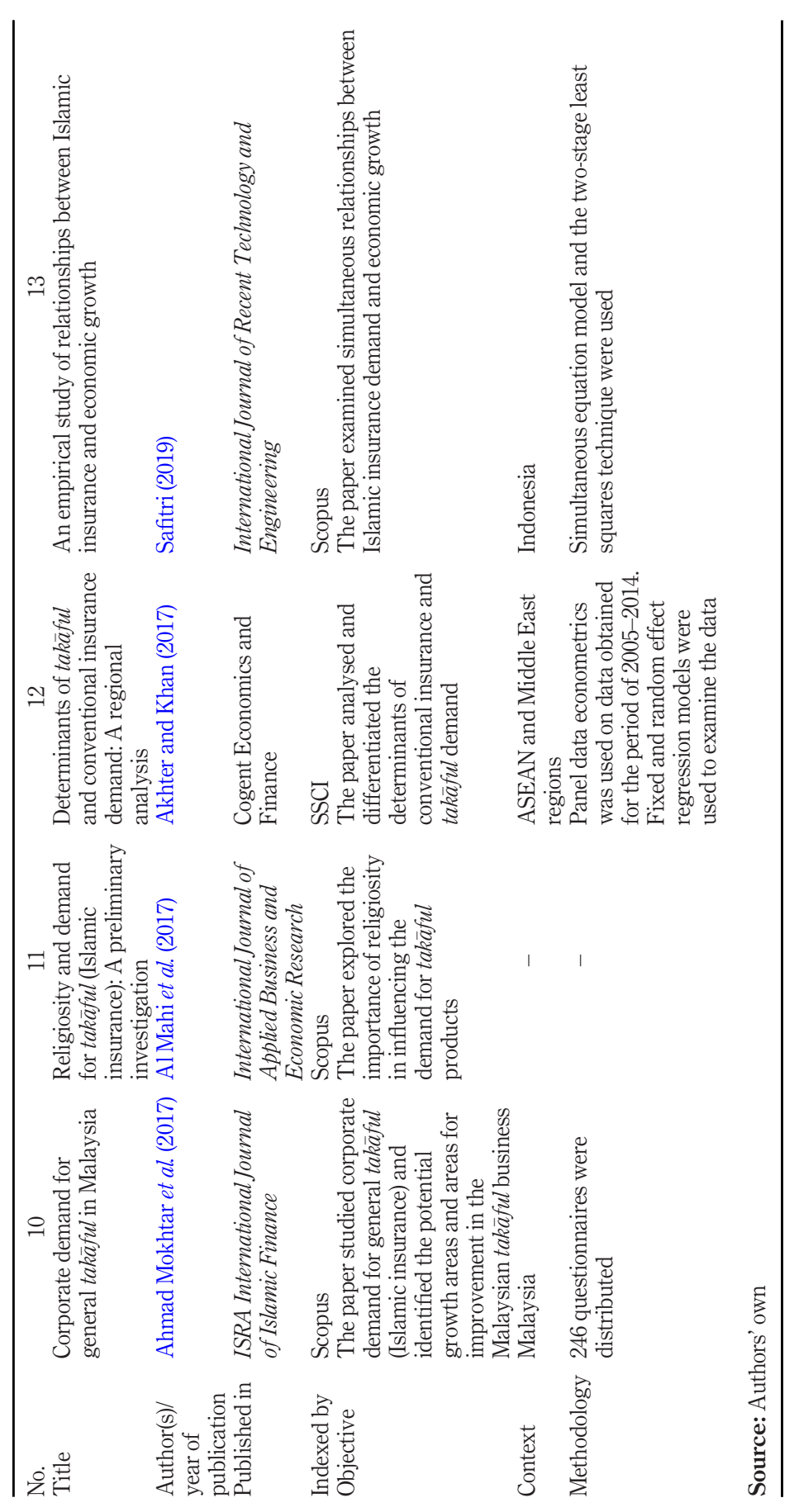

Takāful demand

449

Table 1. 
$\mathrm{IJIF}$

12,3

450

Table 2.

Inclusion and exclusion criteria

\section{Research data}

This paper classified the research data into two, namely, primary and secondary data. Six articles' discussions on takâful demand were based on primary data, while the remaining six used secondary data. Interestingly, this review found that only two articles, one using primary data (Hamid et al., 2009) and the other using secondary data (Ahmad Mokhtar et al., 2017) focussed on corporate demand on takaful. Table 3 shows the research data classifications.

\section{Research methods}

There is a mixture of subjects covered under this research area, and a variety of research methodologies are used in the articles. Most of the research used quantitative methodology. For instance, Sherif and Shaairi (2013) collected Malaysian annual data on socioeconomic factors, which explained family takâful demand. Others who used quantitative methodology in their papers were Akhter and Khan (2017), who conducted a regional analysis;

\section{Inclusion criteria}

Relevant based on the keywords, title and abstract Articles published between January 2009 and June 2019 Focus on takâful demand

\section{Exclusion criteria} Written in non-English Did not answer the research questions Duplicate articles on the same study Articles that did not match inclusion criteria

\section{Figure 2.}

Content segmentation framework

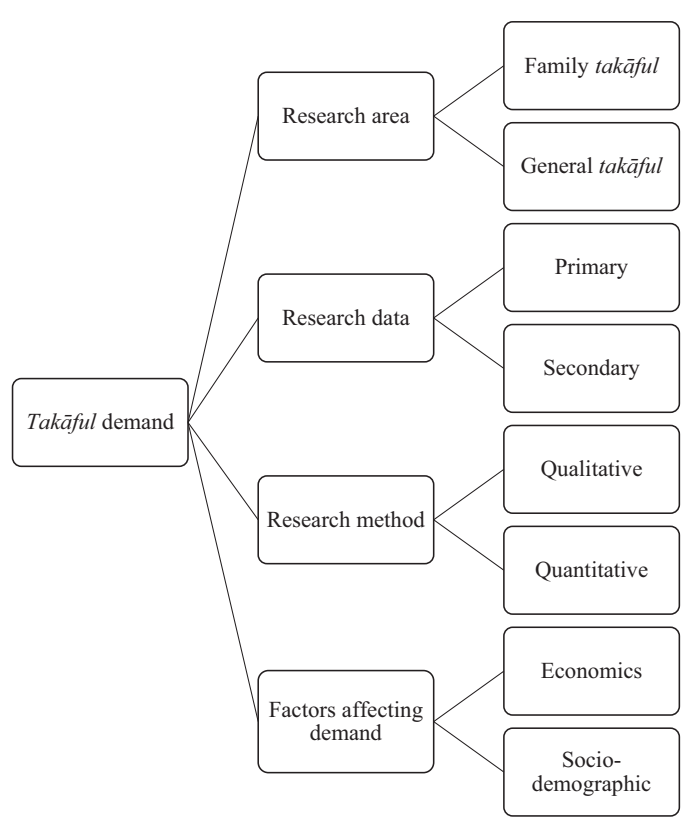

Source: Authors' own 
Ahmad Mokhtar et al. (2017), who examined corporate demand; and Akhter et al. (2017), who focussed on a comparison of Islamic and conventional insurance demand. An alternative to the quantitative method of analysis is qualitative methods, which allow data collection via surveys and focus groups. For example, Turner et al. (2014) used the survey methodology to assess respondents' examination on flood risk, while Hassan et al. (2017) used the survey methodology to conduct screening sessions on health insurance demand.

Factors affecting demand

Many factors have been found to affect family takâful demand; they can be divided into two main categories, namely, economics (micro and macroeconomics) and socio-demography. Amongst the macroeconomic and microeconomic variables that have impacted takaful demand are the development of the financial sector and Islamic banking (Sherif and Shaairi, 2013; Akhter and Khan, 2017), company leverage and size, as well as managerial ownership (Hamid et al., 2009).

In measuring socio-demographic factors, Al Mahi et al. (2017) found a strong relationship between religiosity and takâful demand. In addition, other socio-demographic variables were found to have significantly affected takâful demand; these include income (Sherif and Shaairi, 2013; Akhter and Khan, 2017), urbanisation (Akhter and Khan, 2017), dependency ratio (Sherif and Shaairi, 2013; Safitri, 2019) and education (Sherif and Shaairi, 2013). Table 4 shows the significant demographic and economic factors influencing takaful demand, including the total score for each factor. From the table, education marks the highest score, followed by income and Islamic banking or financial sector deposit and development. The result implies that the factors affecting taka ful demand are not as complex as expected. This is good news, as these takâful demand determinants can be addressed with a well-designed strategy, focussing on awareness-raising and information, as well as setting differentiated and affordable contribution rates.

\section{Conclusion}

This paper provides a systematic review of literature on takâful demand, resulting in an overview of objectives, methodology, context and publication avenues. In addition, content analysis was performed to capsulise the essence of the takaful-demand research into four main segments: research area, research data, research method and factors affecting demand.

Primary data

Secondary data
Coolen-Maturi (2013)

Sherif and Shaairi (2013)

Turner et al. (2014)

Hassan et al. (2017)

Ahmad Mokhtar et al. (2017)

Al Mahi et al. (2017)

Hamid et al. (2009)

Rahman (2009)

Zerriaa and Noubbigh (2016)

Akhter and Khan (2017)

Akhter et al. (2017)

Sherif and Ahmed (2017)

Safitri (2019)

\section{$-2$}


IJIF
12,3

452

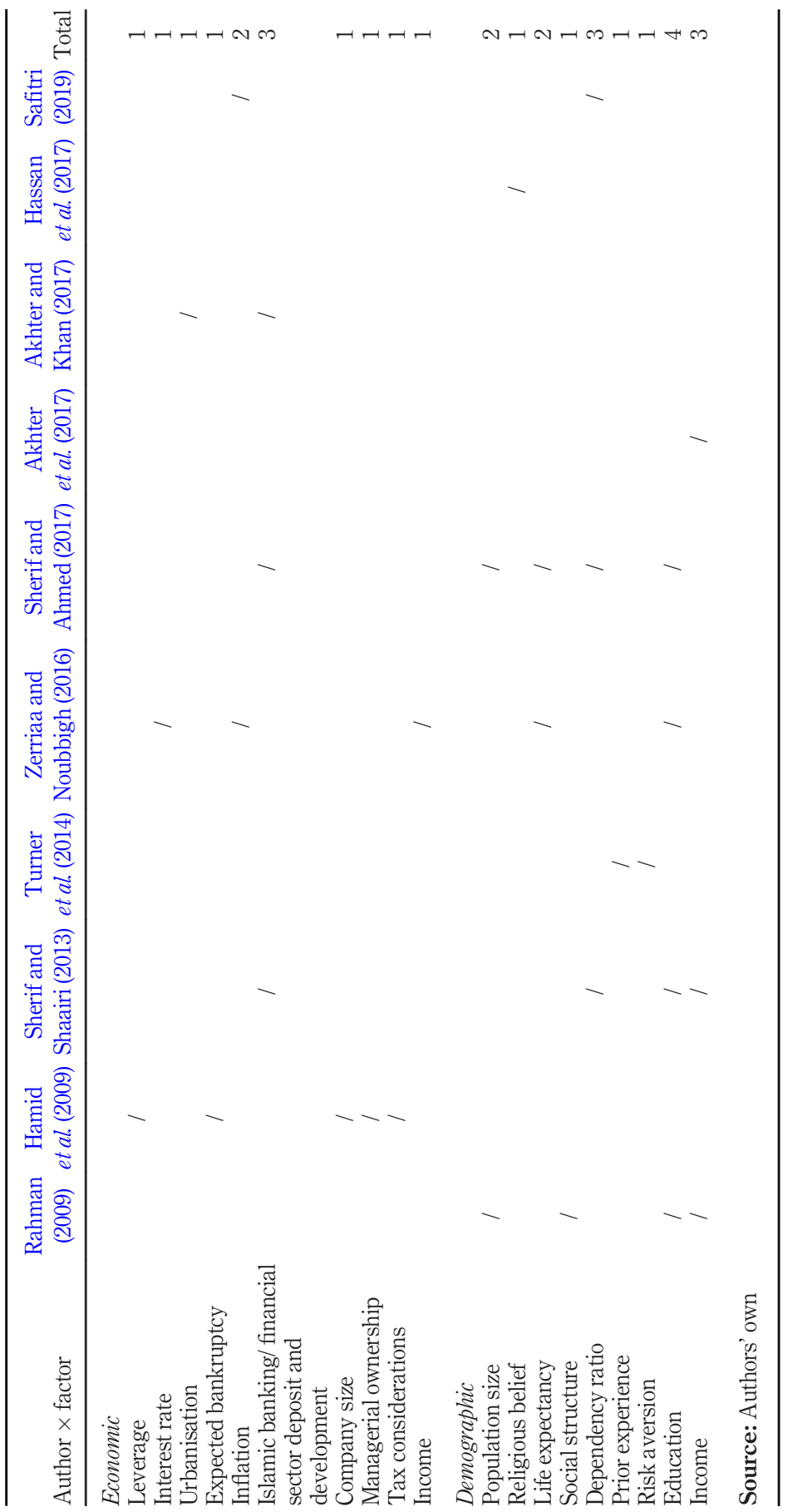

Table 4.

Factors affecting demand 
This paper found that the number of publications in the area of takaful demand has increased significantly over time from two articles in 2009 to six articles in 2017. Although there was no publication on the topic in 2018, one article was published in 2019 in Indonesia. By synthesising and reviewing the literature, the pattern of publication and gaps in previous research has been identified. In addition, this study contributes to the literature by revealing significant demographic and economic factors influencing takâful demand (Table 3).

The review of the articles published in 11 journals as specified in Table 1 reveals that only a limited number of articles have been published in the area of takaful demand. The research articles have identified various factors that influence takaful demand, which can be divided into two broad categories, namely, demographic and economic factors. This paper also confirms that across these 11 journals, research has been conducted using a variety of methodologies, ranging from quantitative to qualitative data.

Practitioners might find the results of this paper useful as it provides a rich overview and outlines various studies conducted in a variety of countries. Furthermore, the paper highlights, which economic and demographic factors were found to have impacted takâful demand and as such, offers practical guidance.

According to Hamid et al. (2009), the corporate sector contributes to the general takâful and conventional insurance total premiums at a rate of more than $50 \%$ of the total premiums. While takaful contribution from the corporate sector is important for the economic development of the institutions and the country, this review paper found that little research has been done on takaful demand from the corporate sector, leaving many possibilities for future research directions in this area.

\section{Limitations}

This review paper has its limitations. Firstly, even though rigorous data searching, locating and collecting were conducted, the limited number of articles reviewed might have excluded out-of-scope articles that may be relevant. However, given the fact that the articles chosen for review were published in the Impact Factor and Scopus indexed journals, the articles were, thus, deemed of adequate quality for analysis. Secondly, this review paper only concentrated exclusively on articles published in English journals, and thus, omitted nonEnglish articles and other types of literature such as conference proceedings, published and unpublished books and book chapters, theses and grey literature. Therefore, the possibility is not denied that other relevant works do appear elsewhere in other languages and publication media not covered in this paper.

\section{References}

Ahmad Mokhtar, H.S., Abdul Aziz, I. and Md Hilal, N. (2017), "Corporate demand for general takâful in Malaysia”, ISRA International Journal of Islamic Finance, Vol. 9 No. 2, pp. 164-184.

Akhter, W. and Khan, S.U. (2017), "Determinants of takaful and conventional insurance demand: a regional analysis", Cogent Economics and Finance, Vol. 5, pp. 1-18.

Akhter, W., Pappas, V. and Khan, S.U. (2017), “A comparison of Islamic and conventional insurance demand: worldwide evidence during the global financial crisis", Research in International Business and Finance, Vol. 42, pp. 1401-1412.

Al-Amri, K. (2015), "Takaful insurance efficiency in the GCC countries”, Humanomics, Vol. 31 No. 3, pp. 344-353.

Al Mahi, A.S.M.M., Sim, C.S. and Hassan, A.F.S. (2017), "Religiosity and demand for takaful (Islamic insurance): a preliminary investigation", International Journal of Applied Business and Economic Research, Vol. 15 No. 24, pp. 485-499. 
$\mathrm{IJIF}$

12,3

Aziz, S., Md Husin, M., Hussin, N. and Afaq, Z. (2019), "Factors that influence individuals' intentions to purchase family takaful mediating role of perceived trust", Asia Pacific Journal of Marketing and Logistics, Vol. 31 No. 1, pp. 81-104.

Berkem, Z. (2014), "Effective supervision of Islamic insurance according to Malaysian experience (19842012)", International Journal of Social Economics, Vol. 41 No. 12, pp. 1220-1242.

Best, A.M. (2013), “A.M. Best's takaful review 2013 edition”, available at: www.ambest.com/resources/ Takaful_review.pdf (accessed 2 February 2020).

BNM (2020), "Financial stability: licensed insurance companies and takaful operators", available at: www.bnm.gov.my/index.php?ch=li\&cat=insurance\&type $=$ TKF \&fund $=0 \& c u=0 \quad$ (accessed 1 September 2020).

Coolen-Maturi, T. (2013), "Islamic insurance (takaful): demand and supply in the UK", International Journal of Islamic and Middle Eastern Finance and Management, Vol. 6 No. 2, pp. 87-104.

EFG (2016), "Insuring success: Saudi Arabia insurance sector", available at: www.efghermesone.com/ News/Index/initiation-of-saudi-insurance-sector-insuring-success-read-full-report- $\quad$ (accessed 3 February 2020).

EY (2013), "Global takaful insights 2013: finding growth markets", available at: www.mifc.com/index. php? $\mathrm{ch}=28 \& \mathrm{pg}=72 \& \mathrm{ac}=59 \& \mathrm{bb}=$ uploadpdf $($ accessed 3 August 2019).

EY (2015), "Malaysian takaful dynamics: Central compendium 2015", available at: www.ey.com/my/en/ industries/financial-services/insurance/ey-malaysian-takāful-dynamics-central-compendium-2015 (accessed 2 February 2020).

Hamid, M.A., Osman, J. and Nordin, B.A.A. (2009), "Determinants of corporate demand for Islamic insurance in Malaysia", International Journal of Economics and Management, Vol. 3 No. 2, pp. 278-296.

Hassan, M.A., Mwaura-Tenambergen, W. and Eunice, M.M. (2017), "Uptake of health insurance among Muslims in Nairobi county, Kenya”, Pan African Medical Journal, Vol. 28, pp. 1-9.

Husin, M.M. and Rahman, A.A. (2016), "Predicting intention to participate in family takaful scheme using decomposed theory of planned behaviour", International Journal of Social Economics, Vol. 43 No. 12, pp. 1351-1366.

Ibrahim, M.D., Salleh, F. and Awang, Z. (2015), "The effects of financial factors on takaful demand in Malaysia”, Journal of Entrepreneurship and Business, Vol. 3 No. 1, pp. 17-29.

Islamic Financial Services Board (2017), "Islamic financial services industry: stability report 2017", available at: www.islamicfinance.com/wp-content/uploads/2017/06/IFSB-IFSI-Stability-Report2017.pdf (accessed 13 July 2019).

Islamic Financial Services Board (2019), "Islamic financial services industry: stability report 2019", available at: www.ifsb.org/sec03.php\#REPORTS (accessed 1 September 2020).

Milliman (2017), "Global takaful report: market trends in family and general takaful", available at: https:/millimancdn.azureedge.net//media/milliman/importedfiles/uploadedfiles/insight/ 2017/takaful-2017-full-report.ashx (accessed 13 July 2019).

Rahman, Z.A. (2009), “Takaful: potential demand and growth”, Journal of King Abdulaziz University, Islamic Economics, Vol. 22 No. 1, pp. 53-70.

Research and Markets (2018), “Global takaful market 2017-2018 and 2023”, PRNewswire, 10 September, available at: www.prnewswire.com/news-releases/global-takāful-market-2017-2018-2023300709652.html (accessed 5 August 2019).

Safitri, K.A. (2019), "An empirical study of relationships between Islamic insurances and economic growth", International Journal of Recent Technology and Engineering, Vol. 7 No. 6, pp. 1036-1043.

Sherif, M. and Ahmed, S. (2017), "Family takaful in developing countries: the case of Middle East and North Africa (MENA)", International Journal of Islamic and Middle Eastern Finance and Management, Vol. 10 No. 3, pp. 371-399. 
Sherif, M. and Shaairi, N.A. (2013), "Determinants of demand on family takaful in Malaysia”, Journal of Islamic Accounting and Business Research, Vol. 4 No. 1, pp. 26-50.

Tranfield, D., Denyer, D. and Smart, P. (2003), "Towards a methodology for developing evidenceinformed management knowledge by means of systematic review", British Journal of Management, Vol. 14 No. 3, doi: 10.1111/1467-8551.00375, (accessed 29 July 2019).

Turner, G., Said, F. and Afzal, U. (2014), "Microinsurance demand after a rare flood event: evidence from a field experiment in Pakistan", The Geneva Papers on Risk and Insurance: Issues and Practice, Vol. 39 No. 2, pp. 201-223.

Zerriaa, M. and Noubbigh, H. (2016), "Determinants of life insurance demand in the MENA region", The Geneva Papers on Risk and Insurance: Issues and Practice, Vol. 41 No. 3, pp. 491-511, doi: 110.1057/gpp.2016.

\section{About the authors}

Maizaitulaidawati $\mathrm{Md}$ Husin, $\mathrm{PhD}$, is an experienced academician with strong enthusiasm and passion for Islamic banking and finance. She is currently a Senior Lecturer at the Azman Hashim International Business School, Universiti Teknologi Malaysia. She has over 12 years of experience in teaching and supervision. Maizaitulaidawati holds a $\mathrm{PhD}$ in Islamic Economics from the University of Malaya, MSc in Banking and BBA in Finance. She is also a certified Islamic financial planner in Malaysia. Maizaitulaidawati Md Husin is the corresponding author and can be contacted at: maizaitulaidawati@gmail.com

Razali Haron, $\mathrm{PhD}$, is currently an Associate Professor at the International Islamic University Malaysia (IIUM), Institute of Islamic Banking and Finance, Director of IIUM Sharīah Advisory Services Sdn. Bhd., member of investment sub-committee at IIUM and former Deputy Dean (Research and Publication) of the Institute. He has extensive experience in the corporate sector, covering brokerage dealings, fund management, unit trust and capital market.

For instructions on how to order reprints of this article, please visit our website: www.emeraldgrouppublishing.com/licensing/reprints.htm Or contact us for further details: permissions@emeraldinsight.com 